\title{
Third Sector Organizations in Québec and the New Public Action in Community Development
}

\author{
Sébastien Savard \\ University of Ottawa \\ Denis Bourque \& René Lachapelle \\ Université du Québec en Outaouais
}

\begin{abstract}
This article presents the context for and particular relations between the state and third-sector organizations in the province of Québec. A typology inspired by Coston and developed by Proulx, Bourque, and Savard is used to describe interactions between these actors. The article documents how an agreement that the private Fondation Lucie et André Chagnon signed with the Government of Québec had an impact on community organizations that respond to the social needs of vulnerable groups. A major repercussion has been the relegation of third-sector organizations to a model between subcontracting and coproductive. This is notable, as the sector had managed to establish itself as a central actor during the previous twenty years, particularly in health and social services, participating in the co-construction of public policies.
\end{abstract}

\section{RÉSUMÉ}

Cet article aborde la question des relations entre les organismes communautaires et l'État au Québec en mettant l'accent sur le contexte particulier et les dimensions qui les distinguent dans cette province. Une typologie adaptée de Coston par Proulx, Bourque et Savard est utilisée pour encadrer cette réflexion. Nous discutons de l'impact de l'arrivée de la Fondation Lucie et André Chagnon (FLAC) sur le rôle des organismes communautaires après la signature d'une entente entre la FLAC et l'État québécois. Nous observons qu'une des conséquences de cette entente a été de confiner les organismes communautaires à un rôle allant de la sous-traitance à la coproduction alors que, depuis vingt ans, ces organismes avaient réussi à s'établir comme partenaires centraux en contribuant, en co-construction avec l'État, à l'élaboration de politiques publiques.

Keywords / Mots clés Third-sector organizations; Partnership; Québec; Private foundation; Community organization / Co-construction; Partenariat; Fondation privée; Organisme communautaire 


\section{Savard, Bourque, \& Lachapelle (2015)}

\section{INTRODUCTION}

The third sector has been invited over the past 30 years to enrol in a "partnership" with the state, characterized by the participation of third sector community organizations (TSCOs) in public policy development. This "Québec model" that responds to health needs of individuals and communities is a hybridization among the Anglo-Saxon heritage of the welfare state, the American model of a community-based approach, and the republican model of centralizing the French state (Savard \& Bourque, 2014). Over the past 30 years, relations between the state and TSCOs have intensified and taken many different forms, depending on the areas of intervention. Some models offer opportunities for TSCOs to participate in the co-construction of responses to social and health problems lived by individuals and communities. This was the case in the field of early childhood services (including child care), which are now supported by a progressive public policy involving a configuration that includes for-profit organizations, public agencies, and nonprofit organizations. The latter form the majority among the three and are called early childhood centres (centres de la petite enfance or CPEs), wherein parents hold the majority of seats on the boards. Since these centres receive significant financial contributions from the provincial government, fees for parents were capped at $\$ 7$ per day until January 1, 2015 (yet, fees are adjusted based on parental income and range from $\$ 7$ to $\$ 20$ per day). Other configurations assign a role to TSCOs that is centred primarily on the provision of services or programs whose strategic choices have been determined outside local jurisdictions.

The objective of this article is to analyze the impact of the arrival of a new player, a private foundation, on the role of third sector community organizations in the field of health and social services in Québec. Firstly, we started by presenting the social and political context in which the TSCO and the Québec government developed their partnership. Secondly, we discuss a model or typology adapted from Coston (1998) that we developed to describe the multiple configurations that the relationship between a TSCO and the state can take in the province of Québec. The third section of this article is the core of our subject matter. In this part, we expose how the Fondation Lucie et André Chagnon (FLAC) has modified both the function and the role of the TSCO in communities where it operated. In the final section, we postulate on possible future developments, considering the recent evolution of the attitude demonstrated by FLAC representatives and their will to engage TSCOs in a way that is more respectful of their historic engagement in the response to the health and social needs of vulnerable populations.

\section{PARADOXICAL PARTNERSHIPS}

Partnerships are linked to the notion of paradoxical dynamics because they relate simultaneously to disparate logics and embrace both the potential democratization of the public management of the social sphere and the risk of instrumentalizing TSCOs (Lamoureux, 1994). Thus, on one level, Duperré (1992) considers that partnerships are the result of both a descending logic (government institution policies on community use) and an ascending logic (demands by social actors, including TSCOs, for autonomy and leverage). We may add, however, that on a second level, each of these logics is itself fraught with paradoxical dynamics. Thus, the descending logic is itself composed of two paradoxical logics originating with the state, identified by Lamoureux (1994) as the logic of according leeway to partnerships in terms of their supervision and control (TSCO participation and empowerment versus technocratic management strategy). The ascending logic, as well, is composed of two logics identified by Proulx (1997) as (1) the autonomist, which is the result of demands from TSCOs for the self-determination of practices; and (2) the complementarist, in the form of demands for integration into state policy that originate in the descending logic and are often the result of financial need. Figure 1 illustrates this paradoxical dynamic. 


\section{Figure 1: Paradoxical dynamic of partnership sources}

Top-down logic

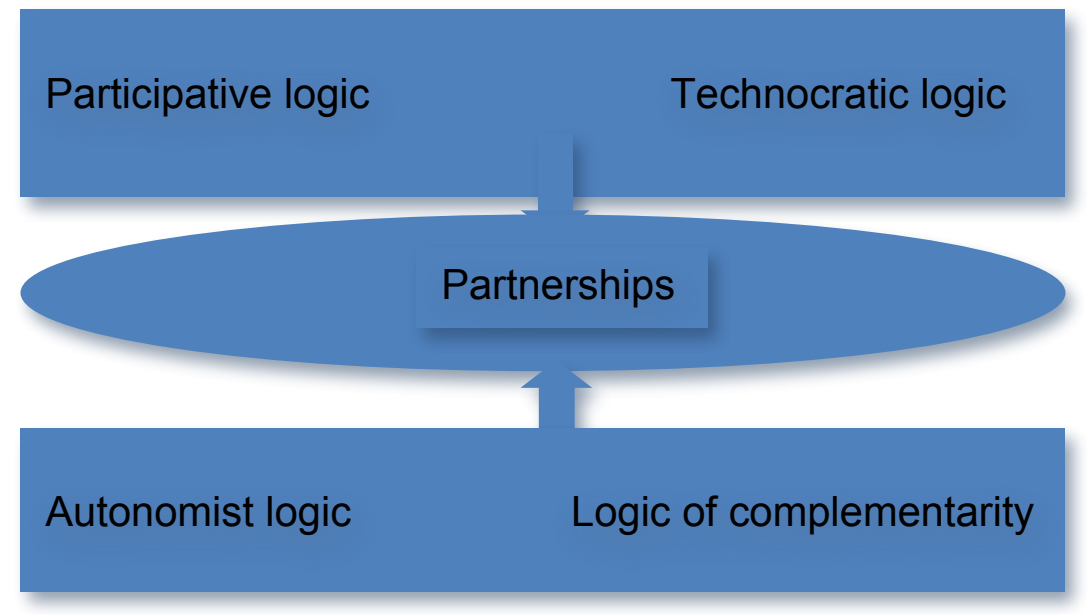

Source: Bourque, 2008

The development of relationships and interfaces between social actors is conditioned by the social, legislative, and political contexts of the society in which they evolve. An actor is understood here not to be holding a role, but to be taking action in a given situation (Crozier \& Friedberg, 1977). These relationships and interfaces are marked by continual tensions because they are conditioned by three co-existing realities: (1) as a source of funding, they represent a means of survival for many actors, including TSCOs; (2) they represent opportunities to augment capabilities for collective action; and (3) they represent the risk inherent in the instrumentalization of social actors and, potentially, the loss of their independence. There is now a general agreement in the international literature concerned with third sector-state partnerships that TSCOs are being instrumentalized, to the detriment of their specificity and autonomy. This analytical current puts more emphasis on the political and structural determinants of partnership than it does on actors' and organizations' capacity for action. Yet, partnerships are social constructs in which interfacing actors produce relationships that may be located on a continuum that extends from subcontracting to co-construction (Proulx, Bourque, \& Savard, 2007).

\section{PARTNERSHIPS: BETWEEN DEVELOPMENT TOOL AND INSTRUMENT OF THE TECHNOCRATIC GOVERNANCE OF THE SOCIAL SPHERE}

Around the world, the management of public services is increasingly conducted in concert with civil society (Proulx et al., 2007), particularly in the field of local services. The state and the public sector increasingly share the delivery of public services, to varying degrees, with other actors such as private for-profit organizations, private families, or TSCOs. In this context, some now fear that states will attempt to divest themselves of certain responsibilities in order to confer them on TSCOs by way of partnerships. Moreover, in developed countries, the state does not act unequivocally, but pluralistically. Depending on circumstances, it oscillates between the polarities of state regulation (notably in the case of income security) and self-regulation, particularly in the field of social services and community development. In light of the failure of centralized, technocratic management, Lamoureux (1994) considers that partnerships are favoured by many states as a means to bring new actors (such as TSCOs) into the planning and 


\section{Savard, Bourque, \& Lachapelle (2015)}

organization of collective public services. The partnership is therefore seen to be the result of social change and the concomitant changes in the role of the state and, at the same time, seen as a vector (conductor and generator) of those same changes. This conception of the partnership is based on an analysis of its paradoxical character. It appears that partnerships cannot be considered in terms of binary opposition. Indeed, they are the expressions of often paradoxical, and even contradictory, purposes, as is demonstrated by their simultaneous relation to disparate logics.

Thus, we consider that partnerships may be seen as relationships that are never simple and are often characterized by asymmetrical (unequal power and resources) and hierarchical (power struggle) relations between actors (Lévesque \& Mager, 1992). Partnerships are fundamentally political processes that create relations and tensions between actors whose organizational interests, approaches, and cultures are often disparate, if not outright contradictory. The results generally stem from compromise, defined by Lévesque and Mager (1992, p. 28) as the "search for the common effects of differing approaches" and by Lamoureux (1994, p. 185) as a process "which infers that the actors can agree on common objectives, but that they do so based on distinct identities, which they partly surrender in the process."

The work of Proulx et al. (2007), inspired by Coston (1998), concludes that interfaces between the state and the third sector can crystallize along a continuum on which the authors have set down seven distinct types of interface. This typology rests on the analysis of three main parameters, that is to say, the degree of openness of the government to institutional pluralism (including the third sector); the degree of formalism of the relations; and the balance of power (see Figure 2). In this model, the further to the left of the continuum, the more limited is the openness of the government to institutional pluralism. On the other hand, the "co-construction" type represents the highest level of openness of the government to the third sector. In the same way, the types of relations to the left of the continuum are those in which the balance of power is clearly to the advantage of the government, while it is shared more with the third sector toward the right of the continuum. Finally, the parameter relating to the degree of formalism of the relations makes it possible to decide between the types of relations according to their more or less formal character-even if does complicate the model somewhat. Each one of the seven types of relationship is characterized thusly:

- The "competition" relationship, whereby government agencies and third sector organizations are engaged in a competition dynamic (e.g., for access to grants or subsidies).

- The "subcontracting" relationship, whereby the government, while remaining an important player, delegates operations to third sector organizations for delivery of certain services.

- The "third party" relationship, whereby the government delegates both operations and responsibilities to third sector organizations, thus sharing a substantial degree of its prerogatives and limiting its influence on organizational activities.

- The "coexistence" relationship, whereby the government is sympathetic to the activities of third sector organizations but not necessarily proactive in supporting them. The relation is often limited to the exchange of information through "non- constraining coexistence."

- The "supplementarity" relationship, whereby the government sets up public services according to average preferences of the population, but agrees to partly support the minority preferences with which third sector organizations deal. The advantages of selfsustaining services by third sector organizations are thus combined with official ones in supplementing governmental services. 
- The coproductive relationship, where third sector organizations may participate in decisionmaking regarding the means and processes of deployment, particularly as a part of the organizational aspects of services (Jetté \& Vaillancourt, 2009). This means that these organizations are able to influence the manner in which services are offered to the public, but without the possibility of influencing the general direction and the strategic choices around the goals to pursue.

- The "coconstruction" relationship, whereby the government shares its responsibilities and operations with the third sector while each party maintains its autonomy, values, and mission. Co-construction also implies the participation of third sector organizations in the development of public policies. To indicate this type of relation, we sometimes refer to "mutualist strategy" or "rationalized welfare pluralism."

Figure 2: Typology of relationships between government

\begin{tabular}{|l|l|l|l|l|l|l|l|}
\hline Dimensions & Competition & Subcontracting & $\begin{array}{l}\text { Third } \\
\text { party }\end{array}$ & Coexistence & Supplementary & Coproduction & Coconstruction \\
\hline $\begin{array}{l}\text { Openness to } \\
\text { institutional } \\
\text { pluralism }\end{array}$ & Low & Moderate & Moderate & Moderate & High & High & High \\
\hline $\begin{array}{l}\text { Symmetry of } \\
\text { power } \\
\text { relationship }\end{array}$ & Low & Low & Moderate & Moderate & Moderate & Moderate & High \\
\hline $\begin{array}{l}\text { Intensity of } \\
\text { relationship }\end{array}$ & Low & High & Moderate & Low & Moderate & High & High \\
\hline $\begin{array}{l}\text { Formality of } \\
\text { relationship }\end{array}$ & Low & High & High & Low & Moderate & High & High \\
\hline
\end{tabular}

Source: Proulx, Bourque, and Savard (2007), adapted from Coston (1998)

This is dependent on the credibility and the political clout that TSCOs succeed in developing individually and collectively. We therefore used this model to study (Savard \& Proulx, 2012) the relationship between public social and health service agencies and third sector organizations in specific sectors, such as services for frail elderly people, employability, intellectual disability, and Youth Services. The methodologies applied to conduct our research were quantitative, through the use of a questionnaire, and by qualitative through semi-structured interviews.

The questionnaire includes 35 questions that address the four dimensions of the typology. For example: Does the administration of the public organization or establishment with which you have a relationship recognize the expertise you have developed in your sector of activity? What is the average frequency of your formal and informal interactions with the public organization or establishment with which you have a relationship (meetings, phone calls, written communications, etc.)? Does your organization have a written agreement, contract or collaboration protocol 


\section{Savard, Bourque, \& Lachapelle (2015)}

with the public organization or establishment with which you have a relationship? When planning policies, programs and action plans affect a common public, would you say that the public organization or establishment with which you have a relationship consults your organization?

Answers to the questions were graded on a Likert scale from 1 to 5 and, depending on the scored obtained for each dimension of the typology, determine what kind of relationship the TSCO is engaged in with a specific public agency. Fifty-two respondents out of a possible 54, who were all executive directors or coordinators of a TSCO, filled out the e-questionnaire from March to June 2010. The semi-structured interviews were conducted with 15 TSCO managers (executive directors and coordinators) with a view to obtaining more complete and insightful information and to validate the results obtained from the questionnaire.

The results analysis leads us to observe that TSCOs have a role and a place in community development and in response to social and health needs. However, at the time of this research (2010), the trend in third sector involvement seemed to focus on a role in the subcontracting of services or programs. This is due to the fact that local community organizations still have little influence on the strategic choices of targets and orientations that facilitate intervention geared to problems or needs identified at the national level. In some areas, such as rural development, local actors (e.g., TSCOs) have a greater autonomy and a greater role in decision-making that place both of which place them in a better position in terms of the co-construction of policies and programs. But in the area of health and social services in general, there is more of an instrumental relationship (for more information on the results of this research, refer to Savard \& Proulx, 2012).

Vaillancourt (2008) proposes using the concept of co-construction to designate TSCO participation in the elaboration of public policy. Public programs and policies are, in a way, always co-constructed (whether via neoliberal or corporatist co-construction). All the same, as Vaillancourt (2008) points out, the quest for the public good requires a more democratic co-construction of public programs and policies, which necessitates the pluralist participation of civil society stakeholders in the elaboration of programs (the institutional dimension) as well as in their implementation (the organizational dimension, or co-production).

Co-construction refers to dimensions that are not mainly organizational in the sense of the organization of products and services but, rather, institutional and political in the setting of overall aims and the principles underlying policies and programs. It is for these reasons that co-construction, in our opinion, must be applied to more than just the management or delivery of programs and services. Indeed, it must also include the elaboration of their aims and rules of operation based on a principle of mutual recognition and statutory equality between protagonists, as well as the democratic and significant participation of concerned individuals and communities. Thus, partnerships oscillate between polar opposites: on one hand, the democratization of public services, programs, and policies (characterized by co-construction); and at the other extreme, the subordination of civil society to a neoliberal or technocratic system of management centred on the disengagement or non-involvement of the state (characterized by subcontracting), especially in light of the more recent phenomenon of partnership between government and private philanthropic foundations in response to new social and community needs.

The 1980s and 1990s were characterized in Québec by a partnership favourable to community innovation and social economy, and this was made possible by the presence of an emerging co-construction model. In the 2000s, the New Public Management has led to a New Public Action (Gaudin, 2007), which seeks to activate local dynamics and community action with rules and logic that challenge the TSCOs in their practices. The results of our initial research may well indicate that the increasing presence of philanthropic foundations in recent years constitutes an 


\section{Savard, Bourque, \& Lachapelle (2015)}

interesting development. The most important of these foundations are major partners in a kind of corporatist coconstruction relationship with the state. At the same time, rather than operating along the lines of TSCOs, they function more like businesses inspired by commercial logic.

\section{THE NEW PUBLIC-PRIVATE PARTNERSHIP}

In Québec, the commercial private sector is much more present than in previous years and is growing quickly in the field of health services in terms of how it provides social welfare and related services. Currently, the commercial private sector is focused mainly on housing for seniors. However, in the majority of domains related to community or local services in which that sector is active (such as home care services for people with loss of autonomy or in the field of child care), it is the TSCOs that have a dominating presence. This situation can be explained by the historical establishment of these services as a result of initiatives from civil society that have been recognized and financially supported by the state under more or less co-constructed public policy. It is the same in the areas of community support for individuals and families, mutual aid, temporary shelters for people in difficult circumstances, community development, and the prevention of social problems.

Our research is directed toward a more recent phenomenon in Québec, namely the use of partnerships between government and private philanthropic foundations in response to new social needs. The emergence in recent years of the Lucie and André Chagnon Foundation (acronym FLAC in French) arouses strong reactions from TSCOs, associations, and academics (Chamberland, Gazzoli, Dumais, Jetté, \& Vaillancourt, 2012). From its launch in 2000, FLAC posed a problem in that the source of its capital primarily took the form of a major tax shelter that deprives the Québec provincial government of hundreds of millions of dollars in potential revenue. The FLAC funding base was generated by the sale of a Chagnon-owned communications company (Vidéotron) to another Québec firm (Quebecor). The purchase was made possible by the financial involvement of the public institution Caisse de dépôts et de placements du Québec (CDPQ), which manages pension funds for a segment of the Québec population. In fact, the CDPQ invested $\$ 3.2$ billion in the purchase of Vidéotron and its subsidiaries (including the private network TVA). Since 2007, the Québec government has made contributions through four joint programs in partnership with FLAC to promote support for caregivers of the elderly, the educational success of young people, healthy lifestyles among young people, and the development of children from birth to five years of age. (This $\$ 570$ million funding arrangement will expire in 2017.)

This foundation seems to be the perfect example of the "new philanthropy" that Edwards (2008) characterized for the United States. Specifically, this philanthropy is viewed as a private action that not only supports existing organizations, but also assumes the form of an investment that will bring benefits in the longer term and demonstrate that strategies employed in the world of private enterprise can also be applied to solve social problems. Edwards (2008) mentions three characteristics that may apply to all new philanthropists:

- Very large sums of money committed to philanthropy that mainly resulted from remarkable profits earned by a small number of individuals;

- A belief that methods drawn from business can solve social problems and are superior to the other methods in use in the public sector and in civil society; and

- A claim that these methods can transform society, rather than a reliance on greater access to socially beneficial goods and services. (pp. 31-32) 


\section{Savard, Bourque, \& Lachapelle (2015)}

According to Lesemann $(2008$, p. 9), FLAC has a new "offensive political project" in the organization of social services that is rooted in a "strategy of targeting at-risk groups," especially children and young people from certain disadvantaged social groups or regions. The foundation seeks to be a different kind of player-one that not only offers more charitable services in a complementary spirit with the public or voluntary sector, but also "shares and spreads a critique of government action considered ineffective and not sufficiently open to the private sector as such, or to a voluntary sector that should reach performance criteria and be accountable" (p. 9).

\section{Foundations in the third sector}

In Canada, fiscal laws make a distinction between public foundations (e.g., the United Way) and private foundations. The qualifier "private" is not related to a potential commercial or mercantile nature of these foundations, but to their main sources of income and the composition of their boards of directors. Given their nonprofit nature, Chamberland et al. (2012) place private foundations within the scope of the third sector, therein defined as "all social enterprises, community organizations, cooperatives, mutual societies and foundations operating on democratic principles and working to the benefit of communities in a context of general interest and common good" (p. 52).

However, these authors call for refining the analysis of private foundations beyond their nonprofit dimension to include an analysis of their democratic structures, governance, diversity of stakeholders, the effective participation of different protagonists, and the presence or absence of co-construction in the development and implementation of projects. These elements distinguish private foundations from collective organizations in the third sector, particularly in Québec, where there is a profound collective action and associative tradition generally described as "community." Lesemann (2011) states, "Today, there are more than 5,000 groups in Quebec functioning on the basis of deep integration or engagement in the 'community,' offering one form or another of service to people or to the defense and promotion of rights, often with State funding" (p. 92). To this associative way of life must be added some 7,000 social economy organizations that engage 125,000 employees, with a turnover of $\$ 17$ billion. On the other hand, FLAC actually adopts a very different mode of operation than the voluntary and social economy.

\section{A new mode of operation}

The Lucie and André Chagnon Foundation targets four thematic areas, with the general purpose of preventing poverty. These areas are child development from birth to five years of age; support for caregivers of the elderly; promoting academic success; and healthy lifestyles among young people. FLAC develops a specific program for each of these themes. It becomes actively involved in all stages of the intervention: identification of problems and objectives to pursue, program development and implementation, choice of territories and populations prioritized, financing activities, and evaluation.

Since the identified causes of poverty and targeted problems are related to issues of individual behaviours, action taken centres upon healthy lifestyles and social skills rather than other living and environmental conditions. This is a model of intervention "equally technocratic, and top-down as the government intervention" (Lesemann, 2008, p. 11) and allows for efficient implementation of public-private partnership (PPP) with the state. Intervention is also made possible by the fact that new public policies in the welfare sector in Québec are implemented through the mobilization and coordination of local actors and TSCOs. For example, there is the approach used by FLAC to administer its four programs:

One of the Foundation's approaches is to promote the mobilization of a wide number of civil society actors-organizations, institutions, stakeholders and parents-in order to spark the 


\section{Savard, Bourque, \& Lachapelle (2015)}

creation and implementation of appropriate solutions. We believe that individuals who are are present in children's lives are particularly well-placed to contribute to their development, starting with their parents and family, as well as the local actors who work in the communities where those children live, especially in areas where many of them are living in poverty. (FLAC, 2013, n.p.)

Programs initiated through PPPs call for the deployment of development agents across Québec who offer to assist local representatives in regrouping local committees, which, in turn, define an action plan focused on a given problem observed in the community. This plan will be funded to the extent that it meets the objectives and priorities of the program and on condition that it includes new activities only, rather than funding existing services. Public programs and PPP policies are therefore realized through contributions from TSCOs to address predetermined priorities and, oftentimes, activities. All the same, such programs and policies do not fund the specific mission of these organizations. Thus, in recent years, new funding for a public response to emerging community needs is not being channelled through direct contact with the TSCO; rather, the support is furnished via a PPP, whereby the TSCO is involved in an instrumental relationship model. The third sector is thereby partly marginalized and experiencing repercussions in its operations that have been documented recently (IRIS, 2013).

\section{IMPACTS ON THIRD SECTOR ORGANIZATIONS}

The impacts on TSCOs and local communities must be divided into two categories: first, impacts related to the early implementation of these programs; and second, the most recent impacts. Chamberland et al. (2012) put forward that one of the impacts

is related to the unsightly manner with which the foundation has imposed, in the early years, its social action in bastions of community organizations such as the social development of small communities, support to children and to the elderly. Another criticism concerns the undemocratic way in which the foundation has created a privileged position with the Quebec State and program designers, and that many have seen as directly inspired by the private management model. While the community sector operates from a slow local foundation building movement and deserves, according to many observers, more consideration from a government, FLAC imposes its local role through its substantial financial resources. (p. 51)

Criticism of the performance of deployment programs in their early years is extensive and well documented. Research conducted by the Institut de recherche et d'informations socio-économiques (IRIS, 2013) identifies increasing accountability as an instrument of control, a stronger influence of donors on committees, and the modification of TSCO activities in order to obtain funding. The authors noticed impacts on the evolution of the funding of TSCOs, including the introduction of private-sector logic and the bureaucratization of their environment. These changes threaten the original mission of TSCOs that, due to new requirements imposed by the funder, could limit the function of TSCOs to that of service providers instead of one whereby they defend and promote the varied interests and claims of their members.

Research by Ducharme and Lesemann (2011) reports discomfort related to the imposition of expertise in terms of practice in the field and a transformation of values that guide the actions of TSCOs and local communities. This situation, which tends to invalidate ways of doing things and experiences acquired from practice, "reflects a new logic of action which is equal to new paradigms, both in the scientific field and in the field of governance, which compete with those that have emerged from years of experimentation on the field" (Ducharme \& Lesemann, 2011, 


\section{Savard, Bourque, \& Lachapelle (2015)}

p. 205). These authors add that there is a feeling among the TSCOs that FLAC uses them as cheap labour and that the mode of operation affects their democratic structure in that decisions are made by committees that do not allow representatives of TSCOs to consult their members before final decisions are made.

It is possible to cite other potential impacts on existing or emerging practices from local communities that PPP programs refused to recognize and fund at early stages of deployment. This has weakened and compromised these practices (including innovative ones) given the rule of non-funding of all pre-existing activities. Similarly, the creation of local committees from PPP programs could have had the impact of marginalizing and eliminating local preexisting collective action processes and endogenous processes of consultation or community mobilization.

The major difficulty for TSCOs and communities lies in the requirement to enrol in a program that includes not only objectives, but also strict management rules that exclude support for what is already done (and oftentimes not yet accomplished) due to the depletion of funding for the general mission of the TSCOs. These are not partnership instances or processes insofar as they do not support (or do not favour in their first draft) recognition of what has already been achieved.

The first years of program implementation under PPPs were witness to a trend toward transformation of the Québec model. While the state was considering itself as an "accompanist," the development of the third sector and communities in the 1980s gave way to the co-construction of certain public policies. Since the late 1990s, the state (and other funders) have changed their role to that of "operators or managers," with a growing influence on the community practice in a "top-down" and more hierarchical dynamic, which contrasts with the more democratic approach of the previous period (IRIS, 2013).

\section{POSSIBLE CHANGES}

Although the methods used by the Chagnon Foundation to deploy programs have angered several players during the initial implementation phase (Chamberland et al., 2012), more recent research suggests that the foundation changed some of its practices after the first experiences of consultation and partnership with the third sector and local communities. According to Lesemann (2011), initiatives that were targeting transformation in the offer of services for individuals and strategies used by TSCOs have been confronted by the very modus operandi that the foundation wanted to change. As Lesemann (2011) maintains:

These ways of functioning are not only archaic resistance, conservative, and associated with the defense of corporate interests. They are also the result of years of work experience in popular neighborhoods, as well as knowledge of the areas and their populations. They testify to the sense of democratic traditions, which can be perceived as an obstacle to the effectiveness of persons coming from a business culture, but which are, for those who know the specifics of the land, the conditions for efficiency and sustainable and long-term change. (p. 93)

For Ducharme and Lesemann (2011), some TSCO representatives recognize that FLAC has taken its mistakes into consideration and adjusted its programs. Others argue that there have been changes in the discourse, but the reality remains the same. Participants in their research even mentioned that there is indeed a community mobilization through PPP programs and a bottom-up movement from areas where they are located. The authors point out that in this case, it would be necessary to more thoroughly investigate the role of individuals in the structure of the FLAC and PPP programs to understand the opportunities they have to change and adapt programs according to their perception of community needs. It would also be interesting to know the extent of control and 


\section{Savard, Bourque, \& Lachapelle (2015)}

influence that local protagonists have on projects they implement. However, relationships between TSCOs and FLAC are not identical in all territories. Some territories are better equipped than others or have a long history of mobilization that increases their capacities for negotiation. Lesemann (2008) adds:

The challenge is to know how far community groups and associations involved are ableand it depends on the domain in which they intervene, the ability of the local populations to mobilize-to submit projects based on the local history and identity roots of the involved groups, and to negotiate a partnership that respects their own political dynamics. In brief, to truly co-produce the action, rather than only being subject to the representations of an imaginary 'local community' conceived by technocratic services planners, regardless of whether they come from public agencies or a private foundation. (p. 11)

Among the reasons for the possible change of direction by FLAC, one example lies in the fact that the PPP programs are halfway into their 10-year term and their effectiveness and sustainability come into question. As well, the cultures of dialogue and collective action in Québec have influenced the functioning of PPP programs that were confronted with the limits of their managerial and authoritarian approach to communities and associations. Moreover, the approach to quantification evaluation that FLAC promoted at the outset demonstrated certain limits as well as services or programs externally imposed to local communities.

FLAC itself arrived at this conclusion after analyzing the results observed in the most organized and self-determined territories (FLAC, 2013). The foundation is currently working on a new grant for a project dedicated to developing territory in which issues and priorities would be determined by the local partners themselves. The funding would be dedicated to concerted collective action processes and would support initiatives selected by local representatives, and not according to program priorities.

\section{EFFECTS OF HYBRIDIZATION ON THE QUÉBEC MODEL AND PROSPECTS}

While the public-private partnership between the state and the Chagnon Foundation influences the Québec model in the social field, it does not increase the presence of the private commercial market or reduce public engagement. It influences the state-third sector relationship by increasing the contribution of the latter in the response to certain needs in the social sphere insofar as we consider private, nonprofit foundations to be part of the third sector. In the early years, this public-private relationship excluded voluntary and community movements (and civil society in general) from the conceptualization of PPP as embodied in the four targeted programs. These programs will promote three elements: (1) a programmatic approach (problems, solutions, and activities determined by experts); (2) a managerial mode (quantitative indicators and contracted relationships where TSCOs focus on providing services in which strategic choices are determined by interests outside the communities, etc.); and (3) individualizing action (problems caused by personal choices and behaviours, interventions gounded in at-risk lifestyles adopted by some groups and not in living conditions and environments, etc.).

This is a model that was already present in some public policies inspired by New Public Management (Larivière, 2005) and therefore did not constitute a breach or a change in public action, except with respect to the funding mode. In a prolonged period of fiscal austerity, the new public money in the social field has been invested for a term of 10 years in a PPP, whereby the TSCOs are taking a loss in several ways. These TSCOs, as well as local communities and civil society, have nevertheless played their role as social protagonists to influence decisions because, as pointed out by Ducharme and Lesemann (2011): 


\section{Savard, Bourque, \& Lachapelle (2015)}

The foundations are not private companies or public agencies operating in a world all to themsleves. They make themselves open-to a certain extent-to collective forms of governance and to objectives that reach beyond any mere benefit to their founders (whether from moral considerations, seeking praise or tax deductions). Because foundations operate in a social and political context, the impact of their activities needs to be seen. (p. 62)

These authors add that the interaction between persons who uphold different or even contrary principles of action can transform their respective practices. In their eyes, "that is the meaning of these transformations which are fundamental because they allow us to measure the importance of the hybridization phenomena in action and to identify the nature of action principles that predominantly affect the evolution of the relationship between these organizations" (p. 57). Since early in 2000, and leading up to today, the PPP between the state and FLAC has kept TSCOs from becoming part of a co-construction model that exists in the typology of relationships between the Government of Québec and the third sector.

FLAC was a way for that government to manage social action according to the New Public Management principles, which undermines the public logic (redistributive) and seeks to instrumentalize the associative logic (reciprocity). PPPs cannot be initiated without TSCOs and local communities, on which the existence and effectiveness of the partnerships are dependent and which, in turn, require compromise and open new opportunities for co-construction in the search for better answers to collective needs. It remains to be seen whether these compromises will be based on a partnership that creates opportunities for the participation of the persons concerned, ensures respect for community dynamics, and embraces the original contribution of associations and community organizations.

\section{CONCLUSION}

Partnerships fall into two overlapping categories: instrumentalization, which brings the third sector (excluding private foundations) into line with the implementation of public and private programs and policies; and coconstruction, in which negotiation determines the partners' respective contributions. Consequently, these partnerships carry both a potential for the democratization of collective services as well as the risk of subordination of civil society to a technocratic system. Partnerships can take on a variety of forms that range from subcontracting to co-construction. The latter goes beyond the administration and delivery of programs and services (co-production) and confronts the very definition of their goals and rules of operation on the basis of a principle of mutual recognition and statutory equality between partners.

Within the scope of centralized private or public programs, partnership practices cannot be expected to address the local consequences of structural difficulties. Rather, partnerships can support emerging initiatives that contribute to the creation of conditions whereby local organizations set their own rules of operation when confronting the causes and consequences of problems. These organizations can then develop their capacity for taking appropriate action. The principal challenge inherent in partnership practices is how to successfully take on the role of an instrument of development, rather than that of a cogwheel of technocratic planning and administration. All the same, local organizations must inevitably position themselves within the policies and programs set out by planning and funding institutions whose requirements they have to satisfy, if for no other reason than to obtain the means necessary to put their plans into practice. They must also permit (and perhaps even advocate for) the adaptation of programs to community realities, notably those of local actors such as TSCOs. It has been demonstrated that the effectiveness of programs is greater when they take into account local stakes rather than evidence-based requirements from outside (Bourque, Lachapelle, \& Sénéchal, 2010). 


\section{Savard, Bourque, \& Lachapelle (2015)}

In order to better adapt to the new context and fulfill their potential, partnerships must first break with instrumentalization and operate according to an "endogenous" model-one that empowers third-sector actors and private foundations to have a more profound impact on the function and ultimate objectives of their efforts. Social actors can influence the course of partnerships toward co-construction, even though this type of partnership does remain subject to a paradox: it takes the form of a dynamic that is dependent on a certain balance of power determined by the political influence that TSCOs can achieve and sustain, despite - or even in part, thanks to - new public-private partnerships.

\section{REFERENCES}

Bourque, D. (2008). Concertation et partenariat. Entre levier et piège du développement des communautés. Initiatives series. Québec City, QC: Presses de l'Université du Québec.

Bourque, D., Lachapelle, R., \& Sénéchal, J. (2010). Formes et dynamiques des partenariats locaux entre CSSS et organismes communautaires. Rapport de recherche. Cahier de la CRCOC, 1103. Gatineau, QC: Université du Québec en Outaouais. URL: http://w4.uqo.ca/crcoc/Fichiers/cahiers/1103.pdf [September 14, 2015].

Chamberland, V., Gazzoli, P., Dumais, L., Jetté, C., \& Vaillancourt, Y. (2012, July). Fondations et philanthropie au Canada et au Québec: influences, portraits et enjeux. Cahiers du LAREPPS, No. 12-02. Montréal, QC: École de travail social, UQÀM.

Coston, J.M. (1998, September). A model and typology of government-NGO relationships. Nonprofit and Voluntary Sector Quarterly, 27(3), 358-382.

Crozier, M., \& Friedberg, E. (1977). L'acteur et le système. Paris: Presses universitaires de France.

Ducharme, É., \& Lesemann, F. (2011, Spring). Les fondations et la « nouvelle philanthropie » : un changement de paradigmes scientifiques et politiques. Lien social et politiques, 65, 203-224.

Duperré, M. (1992). Du discours à la réalité dans le partenariat public-communautaire en santé mentale: une expérience au Saguenay-Lac-Saint-Jean. Nouvelles pratiques sociales, 5(2), 131-146.

Edwards, M. (2008). Just another emperor: The myths and realities of philanthrocapitalism. New York, NY: Demos.

Fondation Lucie et André Chagnon (FLAC). (2013). Constats et apprentissages-Consultation externe. Montréal, QC: Fondation Lucie et André Chagnon.

Gaudin, J-P. (2007). La contractualisation des politiques et la nouvelle action publique. In Y. Luchaire (Ed.), Collectivités territoriales et gouvernance contractuelle, (pp. 19-35). Paris : L'Harmattan.

Institut de recherche et d'informations socio-économiques (IRIS). (2013). Les organismes communautaires au Québec : financement et évolution des pratiques. Montréal, QC: Institut de recherche et d'informations socio-économiques.

Jette, C., \& Vaillancourt, Y. (2009). L'économie sociale et les services de soutien à domicile au Québec: coproduction ou coconstruction? Cahiers du Larepps (09-07). Larepps; Montréal.

Lamoureux, J. (1994). Le partenariat à l'épreuve. Montréal, QC: Éditions Saint-Martin.

Larivière, C. (2005, Autumn). Les risques de la nouvelle gestion publique pour l'intervention sociale. Interaction communautaire, 70, 13-16.

Lesemann, F. (2008, October). L'irruption des fondations privées dans le "communautaire »: une nouvelle gouvernance des services publics? Bulletin de liaison de la Fédération des associations de familles monoparentales et recomposées du Québec, 33(2), 5-11.

Lesemann, F. (2011, Spring). Philanthropie et fondations privées : vers une nouvelle gouvernance du social? Lien social et politiques, 65, 79-97.

Lévesque, B., \& Mager, L. (1992). Vers un nouveau contrat social? Éléments de problématique pour l'étude du régional et du local. In J.-L. Klein \& C. Gagnon (Eds.), Les partenaires du développement face au défi du local (pp. 19-68). Chicoutimi, QC: GRIR, Université du Québec à Chicoutimi. 


\section{Savard, Bourque, \& Lachapelle (2015)}

Proulx, J. (1997). Le partenariat entre l'État et les organismes communautaires dans le cadre de la Loi 120 : l'enjeu de la complémentarité. Mémoire de maîtrise, Université Laval, Québec.

Proulx, J., Bourque, D., \& Savard, S. (2007, September). Interfaces between state and third sector in Québec. Voluntas: International Journal of Voluntary and Nonprofit Organizations, 18(3), 293-307.

Savard, S., \& Bourque, B. (2014, March). The impact of public-private partnerships on the relationship between the state and third sector community organizations in health and social services in the province of Quebec. Paper presented at conference of the International Society for Third-Sector Research, Copenhagen. URL: http://c.ymcdn.com/sites/istr.siteym.com/resource/resmgr/Copenhagen2014/Savard_and_Bourque_Partner sh.pdf [September 12, 2015].

Savard, S., \& Proulx, J. (2012). Les organismes communautaires au Québec: De la coexistence à la supplémentarité. Canadian Journal of Nonprofit and Social Economy Research / Revue canadienne de recherche sur les OSBL et l'économie sociale, 3(2), 24-42.

Vaillancourt, Y., Leclerc, P. (2008). Notes de recherche sur l'apport de l'économie sociale dans la coproduction et la coconstruction des politiques publiques. Cahier de l'ARUC-Innovation sociale et développement des communautés, série Documentation et diffusion, no. 7. Gatineau, QC: Université du Québec en Outaouais.

\section{ABOUT THE AUTHORS / LES AUTEURS}

Sébastien Savard is an associate professor at the School of Social Work (École de service social) at the University of Ottawa. Email: ssavard@uottawa.ca.

Denis Bourque is a full professor at the Université du Québec en Outaouais and Canada Research Chair in Community Organization. Email: Denis.bourque@uqo.ca.

René Lachapelle is a professional researcher at the Université du Québec en Outaouais and Canada Research Chair in Community Organization. Email: renelachapelle@videotron.ca. 